\title{
Multi Objective Multireservoir Optimization in Fuzzy Environment for River Sub Basin Development and Management
}

\author{
D. G. REGULWAR ${ }^{1, *}$, P. Anand RAJ ${ }^{2}$ \\ ${ }^{1}$ Department of Civil Engineering, Government College of Engineering, Aurangabad, India \\ ${ }^{2}$ Water \& Environment Division, Department of Civil Engineering, \\ National Institute of Technology, Warangal, India \\ E-mail: dgregulwar@rediffmail.com \\ Received June 19, 2009; revised July 19, 2009; accepted July 22, 2009
}

\begin{abstract}
In this paper, a multi objective, multireservoir operation model is proposed using Genetic algorithm (GA) under fuzzy environment. A monthly Multi Objective Genetic Algorithm Fuzzy Optimization (MOGAFUOPT) model for the present study is developed in ' $\mathrm{C}$ ' Language. The GA parameters i.e. population size, number of generations, crossover probability, and mutation probability are decided based on optimized values of fitness function. The GA operators adopted are stochastic remainder selection, one point crossover and binary mutation. Initially the model is run for maximization of irrigation releases. Then the model is run for maximization of hydropower production. These objectives are fuzzified by assuming a linear membership function. These fuzzified objectives are simultaneously maximized by defining level of satisfaction $(\lambda)$ and then maximizing it. This approach is applied to a multireservoir system in Godavari river sub basin in Maharashtra State, India. Problem is formulated with 4 reservoirs and a barrage. The optimal operation policy for maximization of irrigation releases, maximization of hydropower production and maximization of level of satisfaction is presented for existing demand in command area. This optimal operation policy so determined is compared with the actual average operation policy for Jayakwadi Stage-I reservoir.
\end{abstract}

Keywords: Optimization, Multi Objective Analysis, Multireservoir, Genetic Algorithms, Fuzzy Logic, Reservoir Operation

\section{Introduction}

In river basin studies, reservoir systems have their unique aspects and a variety of mechanisms are used in defining their operating rules [1]. Most of the water resources optimization problems involve conflicting objectives. The operation of a multi-purpose, multireservoir system consists of conflicting goals and requirements and consequently, several practical operating scenarios may exist. However, there are no standard operating rules, which are applicable to all situations. The successful management and operation of any reservoir system, therefore, lies in the ability to select the appropriate operating policy from amongst the available set of policies. Yeh [2] reviewed reservoir management and operation models. Optimal coordination of the many facets of reservoir systems requires the assistance of computer modeling tools to provide information for rational management and operational decisions. Labadie [3] has reviewed stateof-the-art in optimization of multi reservoir systems.

Genetic algorithms are search algorithms based on the mechanism of natural selection and natural genetics. It is originated in mid 1970s $[4,5]$ and has developed into an effective optimization approach. Oliveira and Loucks [6] have presented operating rules for multireservoir systems by using genetic search algorithms. Using simulation they have evaluated each policy to compute performance index for a given flow series. Wardlaw and Sharif [7] have presented several alternative formulations of a genetic algorithm for reservoir system. Multireservoir systems optimization has been studied by Sharif and Wardlaw [8]. A genetic algorithm approach has been presented by considering the existing development situation in the basin and two future water resource development 
scenarios. Chang and Yang [9] have presented optimizing the rule curves for multi-reservoir operations using a genetic algorithm and HEC-5. Srinivasa Raju and Nagesh Kumar [10] have discussed application of genetic algorithms for irrigation planning. GA was used to determine optimal cropping pattern for maximizing benefits for an irrigation project. Juran Ali Ahmed and Arup kumar Sarma [11] have demonstrated genetic algorithm model for finding the optimal operating policy of a multipurpose reservoir. Multireservoir operation planning using hybrid GA and linear programming have been presented by Reis et al. [12]. They have proposed a new approach using GA and LP to determine operational decisions for reservoirs of a hydro system throughout a planning period, with the possibility of considering a variety of equally likely hydrologic sequences representing inflows. Jothiprakash and Ganeshan Shanthi [13] have developed GA model and applied to Pechiparai reservoir in Tamil Nadu, India to derive the optimal operational strategies. The fundamental guidelines for GA to optimal reservoir dispatching have been presented by Chang Jian-Xia et al. [14]. They have concluded that with three basic operators selection, crossover and mutation GA could search the optimum solution or near-optimal solution to a complex water resources problem. They have also considered alternative formulation schemes of GA. Reis et al. [15] have demonstrated a hybrid method using GA and linear programming to determine operational decisions for a reservoir system over the optimization period. A multi-objective Evolutionary Algorithm (MOGA) to derive a set of optimal operation policies for a multipurpose reservoir system have been presented by Janga Reddy and Nagesh Kumar[16]. One of the main goals in multiobjective optimization was to find a set of well distributed optimal solutions along the pareto front.

Anand Raj [17] has presented multicriteria methods in river basin planning. ELECTRE-I and ELECTRE-II techniques were applied for water resources planning to Krishna river basin, India. Anand Raj and Nagesh kumar [18] have presented ranking of river basin alternatives using ELECTRE. Anand Raj and Nagesh kumar [19] have presented planning for sustainable development of a river basin using fuzzy logic. Simonovic [20] discussed tools for water management. He discussed the complexity of water resources domain and the complexity of the modeling tools in an environment characterized by continuous rapid technological development. Bender and Simonovic [21] have presented a fuzzy compromise approach to water resource systems planning under uncertainty. Panigrahi and Mujumdar [22] have developed fuzzy rule based model for the operation of a single purpose reservoir. The steps involved in the development of the model include construction of membership functions for the inflow, storage, demand and the release, formulation of fuzzy rules, implication and defuzzification. They have applied this methodology to the Malaprabha irrigation reservoir in Karnataka, India. Nagesh Kumar et al. [23] have presented optimal reservoir operation using fuzzy approach. Comparison of fuzzy and nonfuzzy optimal reservoir operating policies have presented by Tilmant et al. [24]. Srinivasa Raju and Duckstein [25] have presented multiobjective fuzzy linear programming for sustainable irrigation planning. This MOFLP model have been formulated for the evaluation of management strategy for the case study of Jayakwadi irrigation project, Maharashtra State, India. Regulwar and Anand Raj [26] have presented development of 3-D optimal surface for obtaining operation policies of a multireservoir in fuzzy environment using genetic algorithm.

With respect to the literature review, it can be said that multiobjective multireservoir optimization gives better operating policies for reservoirs under fuzzy environment. Therefore this work is undertaken for presenting operating policies for a case study to utilize the water resource optimally and also to present maximized level of satisfaction and corresponding operating policy. Also the entire range of optimal operation policies, for different levels of satisfaction i.e., $\lambda$ (ranging from 0 to 1 ), are determined.

\section{System Description}

The multireservoir system in Godavari river sub basin taken for present study consists of Jayakwadi project Stage-I across river Godavari, Jayakwadi project Stage-II across river Sindaphana, Yeldari project and Siddeshwar project across river Purna, and Vishnupuri barrage across river Godavari in Maharashtra state, India. The salient features of reservoirs are presented in Table 1. The schematic representation of the physical system is shown in Figure 1. The irrigation demand and inflow is presented in Table 2.

\section{Model Development}

The objective of the study is to develop optimal operation policies for a multireservoir in a river sub basin. For this a monthly Multi Objective Genetic Algorithm Fuzzy Optimization (MOGAFUOPT) model is developed. The two objectives considered in this study are:

1. Maximization of irrigation releases (i.e., IR)

2. Maximization of hydro-power production (i.e., HP)

$$
\begin{array}{cc}
\operatorname{Max} Z=\sum_{\mathrm{i}} \sum_{\mathrm{t}}(\mathrm{IR})_{\mathrm{it}} & \forall \mathrm{i}=1,2,3,4 \\
\operatorname{Max} \mathrm{Z}=\sum_{\mathrm{i}} \sum_{\mathrm{t}}(\mathrm{HP})_{\mathrm{it}} \quad \forall \mathrm{t}=1,2,3, \ldots \ldots . ., 12
\end{array}
$$

Where $\mathrm{i}$ is number of reservoirs and $\mathrm{t}$ is number of time steps. In the problem formulation, four reservoirs are 


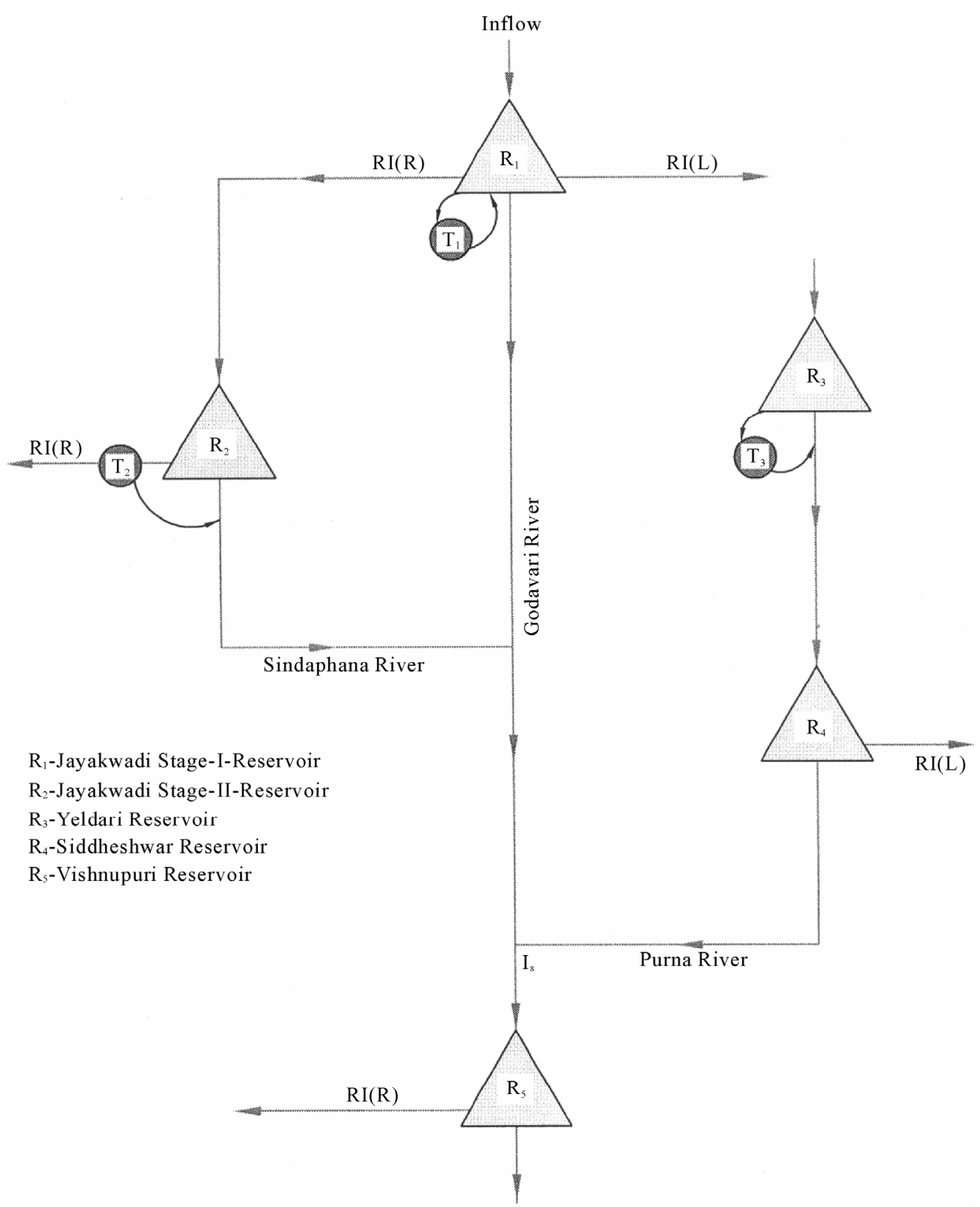

Figure 1. Schematic representation of the physical system.

Table 1. Salient features of reservoirs.

\begin{tabular}{|c|c|c|c|c|c|c|}
\hline \multirow[b]{2}{*}{ Sr. No. } & \multirow[b]{2}{*}{ Salient Features } & \multicolumn{5}{|c|}{ Reservoirs } \\
\hline & & $\begin{array}{c}\text { Jayakwadi Stage-I } \\
\left(\mathrm{R}_{1}\right)\end{array}$ & $\begin{array}{l}\text { Jayakwadi Stage-II } \\
\qquad\left(\mathrm{R}_{2}\right)\end{array}$ & $\begin{array}{l}\text { Yeldari } \\
\left(\mathrm{R}_{3}\right)\end{array}$ & $\begin{array}{l}\text { Siddheshwar } \\
\qquad\left(\mathrm{R}_{4}\right)\end{array}$ & $\begin{array}{l}\text { Vishnupuri } \\
\left(\mathrm{R}_{5}\right)\end{array}$ \\
\hline 1 & River & Godavari & Sindaphana & Purna & Purna & Godavari \\
\hline 2 & State/Country & $\begin{array}{l}\text { Maharashtra State, } \\
\text { India }\end{array}$ & $\begin{array}{l}\text { Maharashtra State, } \\
\text { India }\end{array}$ & $\begin{array}{l}\text { Maharashtra } \\
\text { State, India }\end{array}$ & $\begin{array}{l}\text { Maharashtra State, } \\
\text { India }\end{array}$ & $\begin{array}{l}\text { Maharashtra } \\
\text { State, India }\end{array}$ \\
\hline 3 & Catchment Area $\left(\mathrm{km}^{2}\right)$ & 21750 & 3840 & 7330 & 7770 & 13870 \\
\hline 5 & Live Storage $\left(\mathrm{Mm}^{3}\right)$ & 2171 & 311.30 & 809.77 & 80.96 & 81.67 \\
\hline 6 & $\begin{array}{l}\text { Installed Capacity for hydro- } \\
\text { power generation (MW) }\end{array}$ & $\begin{array}{l}12.0 \text { (Pumped } \\
\text { storage plant) }\end{array}$ & $\begin{array}{c}2.25 \text { (Canal power } \\
\text { house) }\end{array}$ & 15.0 & -- & -- \\
\hline 7 & Irrigable command area $\left(\mathrm{km}^{2}\right)$ & 1416.40 & 938.85 & -- & 615.60 & 337.24 \\
\hline
\end{tabular}


Table 2. Maximum irrigation demand and inflow in reservoirs in $\mathrm{Mm}^{3}$.

\begin{tabular}{|c|c|c|c|c|c|c|c|c|c|c|}
\hline \multirow[b]{2}{*}{ Month } & \multicolumn{2}{|c|}{ Jayakwadi Stage-I $\left(\mathrm{R}_{1}\right)$} & \multicolumn{2}{|c|}{ Jayakwadi Stage-II $\left(\mathrm{R}_{2}\right)$} & \multicolumn{2}{|c|}{ Yeldari $\left(\mathrm{R}_{3}\right)$} & \multicolumn{2}{|c|}{ Siddheshwar $\left(\mathrm{R}_{4}\right)$} & \multicolumn{2}{|c|}{ Vishnupuri $\left(\mathrm{R}_{5}\right)$} \\
\hline & $\begin{array}{l}\text { Irrigation } \\
\text { Demand }\end{array}$ & Inflow & $\begin{array}{l}\text { Irrigation } \\
\text { Demand }\end{array}$ & Inflow & $\begin{array}{l}\text { Irrigation } \\
\text { Demand }\end{array}$ & Inflow & $\begin{array}{c}\text { Irrigation } \\
\text { Demand }\end{array}$ & Inflow & $\begin{array}{l}\text { Irrigation } \\
\text { Demand }\end{array}$ & Inflow \\
\hline Jun & 18.55 & 148.76 & 7.12 & 20.98 & 0 & 72.83 & 33.10 & 7.71 & 35.91 & 16.42 \\
\hline Aug & 25.43 & 610.66 & 37.64 & 96.88 & 0 & 200.36 & 35.23 & 11.97 & 31.69 & 107.32 \\
\hline Sep & 85.79 & 600.0 & 46.02 & 144.17 & 0 & 160.77 & 93.46 & 9.18 & 31.49 & 246.07 \\
\hline Oct & 267.86 & 287.75 & 132.01 & 75.52 & 0 & 123.10 & 77.60 & 1.29 & 31.95 & 79.00 \\
\hline Nov & 228.74 & 196.46 & 127.05 & 10.24 & 0 & 49.48 & 74.68 & 0.57 & 22.68 & 9.91 \\
\hline Dec & 210.88 & 125.53 & 89.43 & 4.27 & 0 & 35.58 & 65.14 & 0.89 & 35.09 & 7.93 \\
\hline Jan & 230.34 & 37.65 & 100.68 & 0.37 & 0 & 32.18 & 65.14 & 1.00 & 38.46 & 1.13 \\
\hline Feb & 85.23 & 21.46 & 30.02 & 0.37 & 0 & 24.23 & 35.50 & 0.39 & 23.65 & 0.00 \\
\hline Mar & 70.06 & 19.56 & 28.98 & 0.16 & 0 & 23.54 & 37.40 & 1.00 & 14.50 & 0.00 \\
\hline Apr & 85.49 & 25.50 & 35.58 & 0.12 & 0 & 13.15 & 30.50 & 0.40 & 19.06 & 0.00 \\
\hline May & 58.20 & 46.58 & 25.88 & 0.06 & 0 & 13.86 & 22.30 & 0.40 & 28.07 & 0.00 \\
\hline Total & 1393.2 & 2528.17 & 681.24 & 396.60 & 0 & 890.17 & 605.2 & 37.01 & 335.5 & 503.74 \\
\hline
\end{tabular}

taken for optimization. The fifth reservoir is considered as downstream control and is incorporated as a constraint in the model. These objectives are subjected to the following constraints:

\subsection{Turbine Release Constraints}

The releases into turbines for power production, should be less than or equal to the flow through turbine capacities for all the months. Also, power production in each month should be greater than or equal to the firm power. These constraints can be written as:

$$
\begin{gathered}
\operatorname{HPR}(\mathrm{i}, \mathrm{t}) \leq \mathrm{TCR}(\mathrm{i}) \quad \forall \mathrm{i}=1,2,3,4 \\
\operatorname{HPR}(\mathrm{i}, \mathrm{t}) \geq \operatorname{FPR}(\mathrm{i}) \quad \forall \quad t=1,2,3, \ldots \ldots . ., 12
\end{gathered}
$$

\subsection{Irrigation Release Constraints}

The irrigation releases should be less than or equal to the irrigation demand on all reservoirs for all the months and should be greater than or equal to the minimum irrigation demand $\left(\mathrm{ID}_{\mathrm{min}}\right)$. Mathematically this constraint is given as:

$$
\begin{gathered}
\mathrm{ID}_{\text {min }}(\mathrm{i}, \mathrm{t}) \leq \mathrm{IR}(\mathrm{i}, \mathrm{t}) \leq \mathrm{ID}_{\text {max }}(\mathrm{i}, \mathrm{t}) \quad \forall \mathrm{i}=1,2,3,4 \\
\forall \quad t=1,2,3, \ldots \ldots \ldots, 12
\end{gathered}
$$

\subsection{Reservoir Storage Constraints}

The storage in the reservoirs should be less than or equal to the capacity of reservoir and greater than or equal to the dead storage for all months. Mathematically this constraint is given as:

$$
\begin{array}{r}
\mathrm{S}_{\text {min }}(\mathrm{i}) \leq \mathrm{S}(\mathrm{i}, \mathrm{t}) \leq \mathrm{S}_{\text {max }}(\mathrm{i}) \quad \forall \mathrm{i}=1,2,3,4 \\
\forall t=1,2,3, \ldots
\end{array}
$$

\subsection{Hydrologic Continuity Constraints}

(6)

These constraints relate to the turbine releases, irrigation releases, release for drinking and industrial water supply which is taken as a constant, reservoir storage, inflows into the reservoirs, Losses from the reservoirs for all months. The hydrologic continuity constraints for all the reservoirs is stated as:

$$
\begin{aligned}
& \text { 1) Reservoir }\left(\mathrm{R}_{1}\right) \\
& \left(1+\mathrm{a}_{\mathrm{t}}(1, \mathrm{t})\right) \mathrm{S}(1, \mathrm{t}+1)=\left(1-\mathrm{a}_{\mathrm{t}}(1, \mathrm{t})\right) \mathrm{S}(1, \mathrm{t})+\mathrm{IN}(1, \mathrm{t})-\operatorname{HPR}(1, \mathrm{t})-\operatorname{IR}(1, \mathrm{t}) \\
& -\operatorname{SPILL}(1, \mathrm{t})-\operatorname{WSR}(1, \mathrm{t})-\operatorname{FCR}(1, \mathrm{t})+\alpha_{1} \operatorname{HPR}(1, \mathrm{t})-\mathrm{A}_{0} \mathrm{e}_{\mathrm{t}}(1, \mathrm{t}) \\
& \forall \mathrm{t}=1,2,3, \ldots \ldots \ldots \ldots . ., 12 \\
& \text { 2) } \operatorname{Reservoir}\left(\mathrm{R}_{2}\right) \\
& \left(1+\mathrm{a}_{\mathrm{t}}(2, \mathrm{t})\right) \mathrm{S}(2, \mathrm{t}+1)=\left(1-\mathrm{a}_{\mathrm{t}}(2, \mathrm{t})\right) \mathrm{S}(2, \mathrm{t})+\mathrm{IN}(2, \mathrm{t})+\alpha_{2} \operatorname{FCR}(1, \mathrm{t})-\operatorname{HPR}(2, \mathrm{t}) \\
& -\operatorname{IR}(2, \mathrm{t})-\operatorname{SPILL}(2, \mathrm{t})-\mathrm{WSR}(2, \mathrm{t})-\mathrm{A}_{0} \mathrm{e}_{\mathrm{t}}(2, \mathrm{t}) \\
& \forall \mathrm{t}=1,2,3, \ldots \ldots \ldots . ., 12 \\
& 3) \operatorname{Reservoir}\left(\mathrm{R}_{3}\right) \\
& \left(1+\mathrm{a}_{\mathrm{t}}(3, \mathrm{t})\right) \mathrm{S}(3, \mathrm{t}+1)=\left(1-\mathrm{a}_{\mathrm{t}}(3, \mathrm{t})\right) \mathrm{S}(3, \mathrm{t})+\operatorname{IN}(3, \mathrm{t})-\operatorname{HPR}(3, \mathrm{t}) \\
& -\operatorname{SPILL}(3, \mathrm{t})-\mathrm{WSR}(3, \mathrm{t})-\mathrm{A}_{0} \mathrm{e}_{\mathrm{t}}(3, \mathrm{t}) \\
& \forall \mathrm{t}=1,2,3, \ldots \ldots \ldots \ldots . ., 12
\end{aligned}
$$




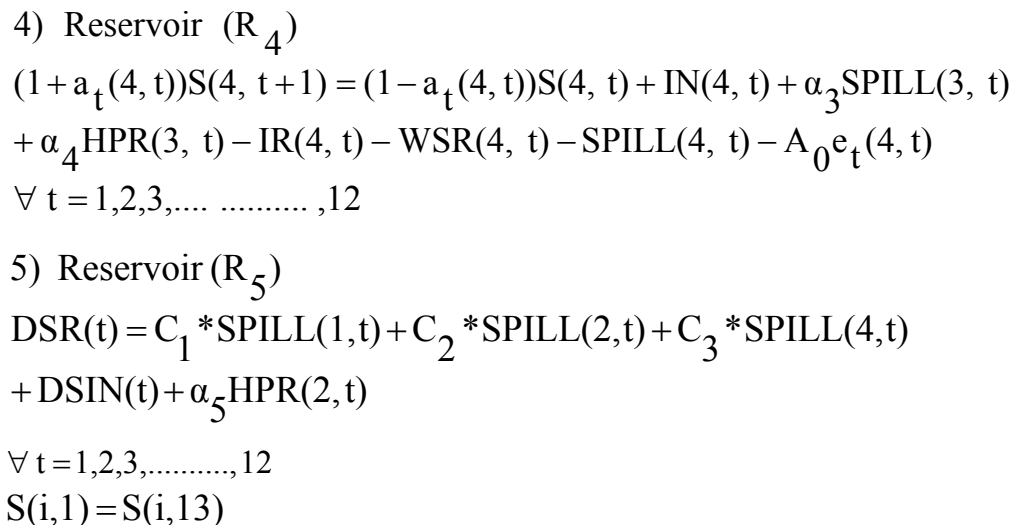

The transition loss for pumping turbine releases back into the reservoir for $\mathrm{R}_{1}$, feeder canal release (FCR) from $R_{1}$ to $R_{2}$, Spills from $R_{3}$ to $R_{4}$, turbine releases (HPR) from $R_{3}$ to reach to $R_{4}$, turbine releases from $R_{2}$ to reach $\mathrm{R}_{5}$, Spills from $\mathrm{R}_{1}$ to reach to $\mathrm{R}_{5}$, Spills from $\mathrm{R}_{2}$ to reach to $R_{5}$, Spills from $R_{4}$ to reach to $R_{5}$ is taken as $10 \%$ in the model. Water supply releases is taken as constant for reservoir $R_{1}$ as $31.63 \mathrm{Mm}^{3}, 3.55 \mathrm{Mm}^{3}$ for $\mathrm{R}_{2}$, and $2 \mathrm{Mm}^{3}$ for $\mathrm{R}_{3}$ and $\mathrm{R}_{4}$ for all months.

\section{Results and Discussions}

For developing optimal operating policies for a multireservoir in a river sub basin a monthly MOGAFUOPT model is developed. By using MOGAFUOPT, the irrigation releases, hydropower production and level of satisfaction $(\lambda)$ is maximized. For this the GA operators used are stochastic remainder selection, one point crossover and binary mutation. For selection of population size, crossover probability, mutation probability and optimal generations, a thorough sensitivity analysis is carried out. The system performance is estimated by taking crossover probability between 0.7 to 1.0 with a increment of 0.05 and mutation probabilities between 0.3 to 0.001 with a decrement of 0.1 up to 0.01 and then the decrement is taken as 0.001 . The population size is varied from 20 to 150 and generation from 20 to 500 . Based on the system performance the optimal population size and optimal number of generations are 130 and 500 respectively. When one of the objectives: $Z_{1}$ (irrigation releases) is maximized, giving no preference to second objective: $Z_{2}$ (hydropower production), the comparison shows that for

$$
\begin{aligned}
& \mu_{\mathrm{Z}_{1}}(\mathrm{x})=\left\{\begin{array}{l}
0 \\
\frac{\left(\mathrm{Z}_{1}-1807.97\right)}{(2218.36-1807.97)} \\
1
\end{array}\right. \\
& \mu_{\mathrm{Z}_{2}}(\mathrm{x})=\left\{\begin{array}{l}
0 \\
\frac{\left(\mathrm{Z}_{2}-85591654.2\right)}{(117394536.3-85591654.2)} \\
1
\end{array}\right.
\end{aligned}
$$

crossover probability 0.7 and mutation probability 0.1 , the maximization (i.e., maximum value of $\mathrm{Z}_{1}: \mathrm{Z}_{1}^{+}$) is achieved. The variation of maximized irrigation releases with respect to different mutation probabilities for selected crossover probability is shown in Figure 2. When $Z_{2}$ is maximized, giving no preference to $Z_{1}$, the comparison shows that for crossover probability 0.9 and mutation probability 0.1 , the maximization (i.e., maximum value of $\mathrm{Z}_{2}: \mathrm{Z}_{2}^{+}$) is achieved. The variation of maximized hydropower production with respect to different mutation probabilities for selected crossover probability is shown in Figure 3. In fuzzy optimization model, when $\lambda$ (level of satisfaction) is maximized, the comparison shows that for crossover probability 1.0 and mutation probability 0.004 , the maximization (i.e., maximization of both the objectives simultaneously) is achieved. The variation of maximized $\lambda$ (level of satisfaction) with respect to different mutation probabilities for selected crossover probability is shown in Figure 4.

The MOGAFUOPT model is developed for multireservoir system as shown in Figure 1 with the objectives 1) to maximize irrigation releases and 2) to maximize hydropower production. The best and worst values for both the objectives i.e., $\mathrm{Z}_{1}$ for irrigation releases $\left(\mathrm{Z}_{1}^{+}\right.$and $\left.\mathrm{Z}_{1}^{-}\right)$and $\mathrm{Z}_{2}$ for hydropower production $\left(\mathrm{Z}_{2}^{+}\right.$and $\left.\mathrm{Z}_{2}^{-}\right)$are determined by considering one objective at a time, ignoring the other. When $Z_{1}$ is maximized, the corresponding value of $Z_{2}$ is considered to be the worst and vice versa. These values are given in Table 3 . These objectives are fuzzified by considering linear membership function. The membership functions for irrigation releases and hydropower production are presented in Equations 13 and 14 respectively.

$$
\begin{array}{r}
Z_{1} \leq 1807.97 \\
1807.97 \leq Z_{1} \leq 2218.36 \\
Z_{1} \geq 2218.36 \\
Z_{2} \leq 85591654.2 \\
85591654.2 \leq Z_{2} \leq 117394536.3 \\
Z_{2} \geq 117394536.3
\end{array}
$$




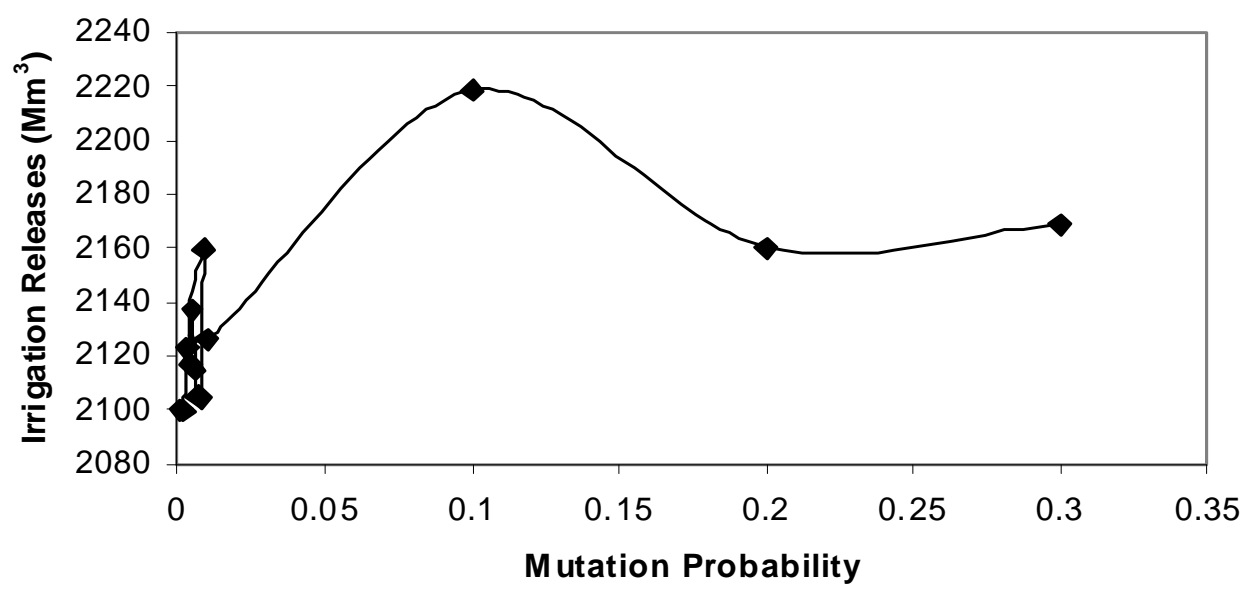

Figure 2. Variation of irrigation releases corresponding to mutation probability for crossover probability 0.7 .

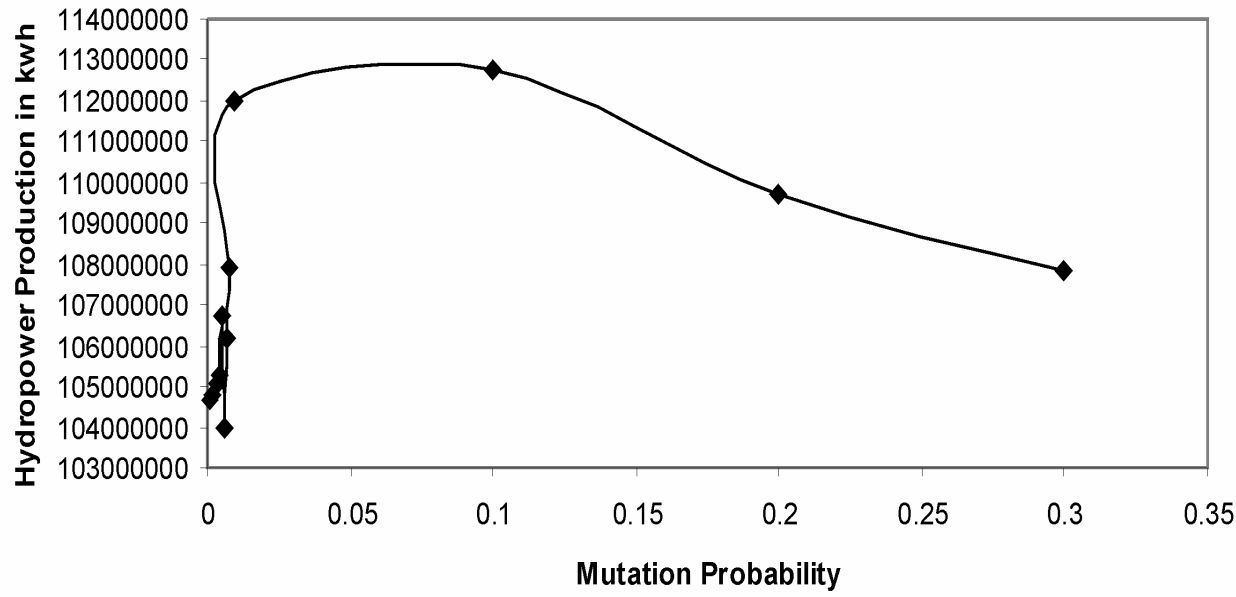

Figure 3. Variation of hydropower production corresponding to mutation probability for crossover probability 0.9 .

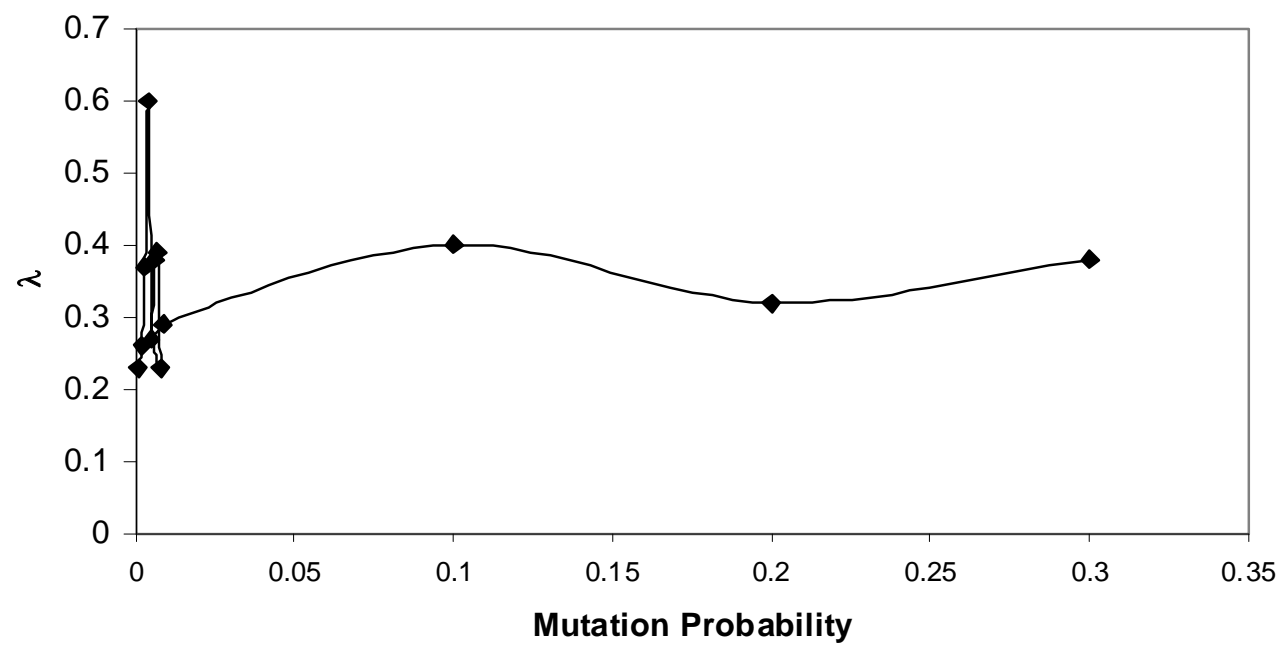

Figure 4. Variation of $\lambda$ corresponding to mutation probability for crossover probability 1.0 . 
Table 3. Best and worst values for objective functions.

\begin{tabular}{lcc}
\hline $\begin{array}{l}\text { Objective Function } \\
\text { (Maximization) }\end{array}$ & Best value $\mathrm{Z}^{+}$ & Worst value $\mathrm{Z}^{-}$ \\
\hline Irrigation releases $\left(\mathrm{Z}_{1}\right) \mathrm{Mm}^{3}$ & 2218.36 & 1807.97 \\
Hydro-power production $\left(\mathrm{Z}_{2}\right) \mathrm{mwh}$ & 117394.5 & 85591.7 \\
\hline
\end{tabular}

These fuzzified objectives are simultaneously maximized by defining level of satisfaction $(\lambda)$ and then maximizing it. The $\lambda$ (Maximum level of satisfaction) was found to be 0.60 . The irrigation releases $\left(\mathrm{Z}_{1}^{*}\right)$ and hydropower produced $\left(Z_{2}{ }^{*}\right)$ corresponding to maximum level of satisfaction are $2054.22 \mathrm{Mm}^{3}$ and $104755.5 \mathrm{mwh}$ respectively. Monthly optimized irrigation releases from reservoirs are shown graphically in Figure 5. Monthly optimized hydropower production from reservoirs is presented in Figure 6.

Decision maker may adopt $\lambda$ value as it is or he may demand different $\lambda$ value. For this, $\lambda$ can be changed for both the objectives as per preferences of decision maker and run the model again to obtain respective solution. For this purpose, the whole range of operation policies with satisfaction levels ranging from 0 to 1 , for both the objectives, are determined. These policies are presented in Table 4.

The comparison between existing operation policy and optimized operation policy is prepared for Jaykwadi stage-I reservoir $\left(\mathrm{R}_{1}\right)$. The results of MOGAFUOPT shows that the annual maximized irrigation releases for Jayakwadi stage-I reservoir $\left(\mathrm{R}_{1}\right)$ is $1166.20 \mathrm{Mm}^{3}$. The annual maximum irrigation demand for this reservoir is 1393.2 $\mathrm{Mm}^{3}$ as per data presented in Table 2. The historical outflow data of reservoir $R_{1}$ for 30 years is analyzed and monthly average outflow for irrigation releases is worked out. Average of 30 years outflow data is taken and it works out to be $1295.6 \mathrm{Mm}^{3}$. The comparison of average existing operation policy and optimized operation policy derived by GA under fuzzy environment is promising. The historic data of existing operation policy for other reservoirs is not obtained. Hence comparison is presented for Jaykwadi stage-I reservoir $\left(\mathrm{R}_{1}\right)$ in Figure 7.

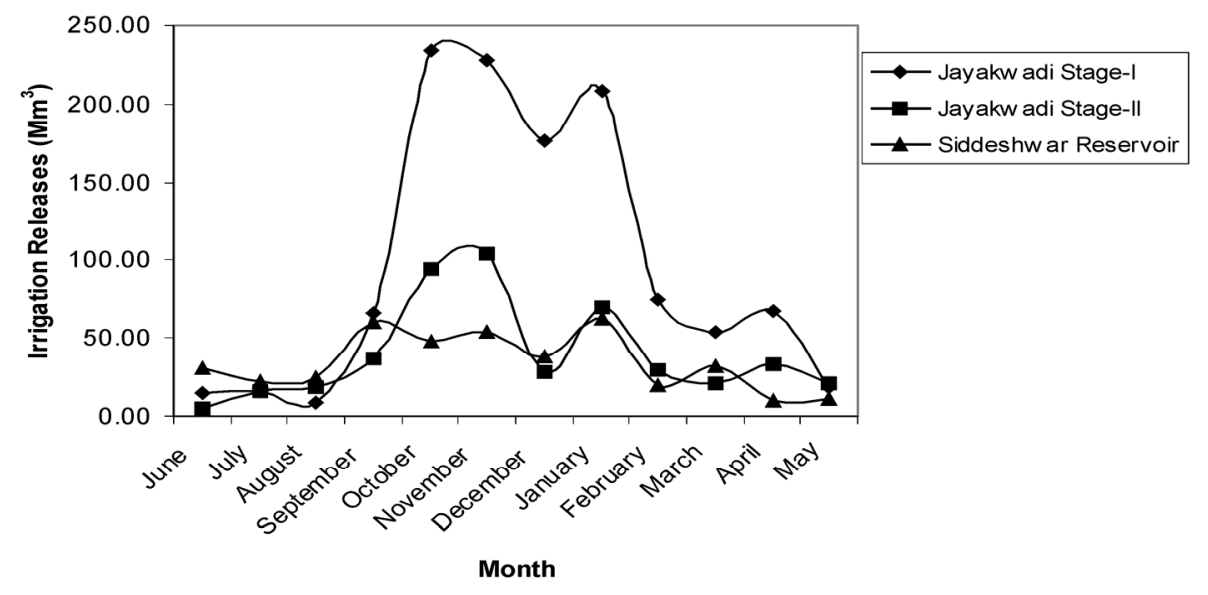

Figure 5. Monthly optimized irrigation releases from reservoirs.

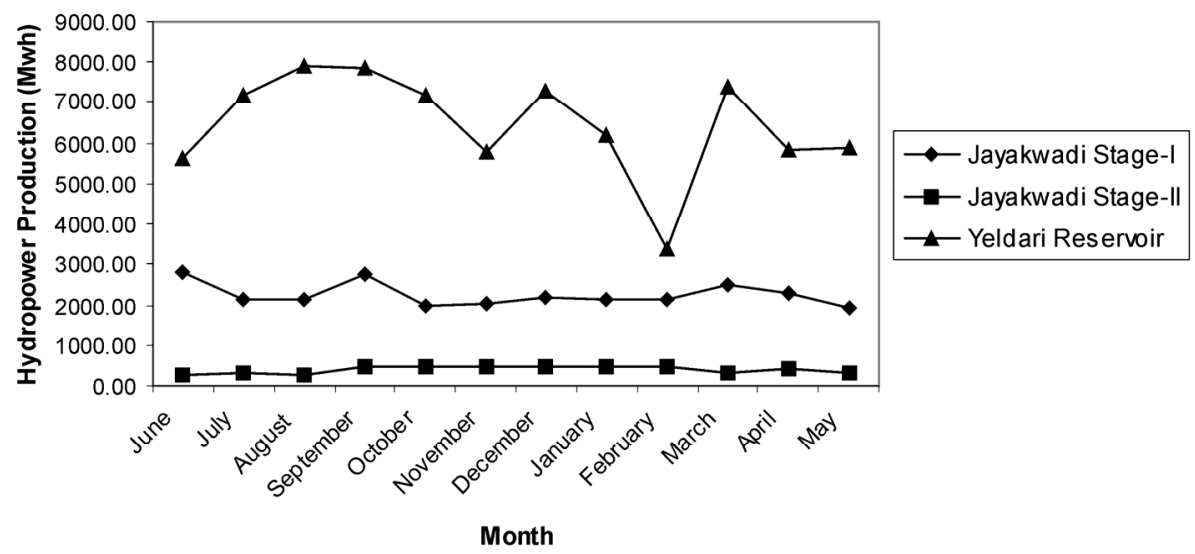

Figure 6. Monthly optimized hydropower production (mwh). 


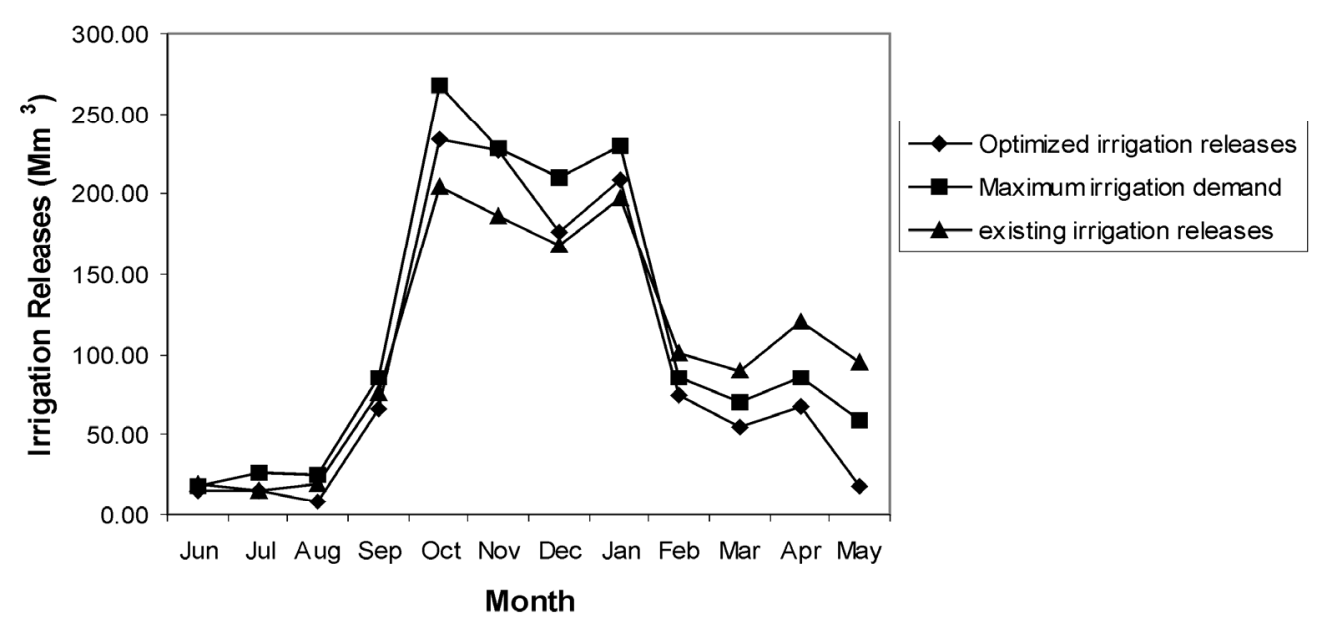

Figure 7. Comparision of irrigaion releases for jayakwadi stage-I project.

Table 4. Solutions of MOGAFUOPT for Different Values of $\lambda$.

\begin{tabular}{ccccc}
\hline \multirow{2}{*}{$\begin{array}{c}\text { Sr. } \\
\text { No. }\end{array}$} & \multicolumn{2}{c}{ Degree of Satisfaction $(\boldsymbol{\lambda})$} & \multicolumn{2}{c}{ Objective Value } \\
\cline { 2 - 5 } & $\boldsymbol{\lambda}_{\mathbf{1}}$ & $\boldsymbol{\lambda}_{\mathbf{2}}$ & $\left.\mathbf{Z}_{\mathbf{1}} \mathbf{( M m}^{\mathbf{3}}\right)$ & $\mathbf{Z}_{\mathbf{2}}$ (mwh) \\
\hline 1 & 0 & 1.00 & 1807.99 & 117394.5 \\
2 & 0.1 & 0.81 & 1849.03 & 111304.5 \\
3 & 0.2 & 0.77 & 1890.07 & 110187.9 \\
4 & 0.3 & 0.70 & 1931.11 & 107869.6 \\
5 & 0.4 & 0.68 & 1972.15 & 107285.8 \\
6 & 0.5 & 0.66 & 2012.18 & 106526.5 \\
7 & 0.6 & 0.60 & 2054.22 & 104755.5 \\
8 & 0.7 & 0.50 & 2095.26 & 101575.2 \\
9 & 0.8 & 0.40 & 2136.30 & 98394.9 \\
10 & 0.9 & 0.30 & 2177.34 & 95214.6 \\
11 & 1.0 & 0.20 & 2218.38 & 92034.3 \\
\hline
\end{tabular}

\section{Summary and Conclusion}

Multiobjective, multireservoir optimization in fuzzy environment by using GA is explored in this study. A multireservoir system in Godavari river sub basin in Maharashtra State, India is considered. A MOGAFUOPT model is developed and applied to the case study. The objective function of the GA model was set to maximize irrigation releases, hydropower production and level of satisfaction $(\lambda)$. The sensitivity analysis for deciding crossover probability, mutation probability, population size and number of generations are presented in the result for this case study. By adopting these GA parameters, irrigation releases, hydropower production and level of satisfaction are maximized and results are presented. The maximum level of satisfaction $\left(\lambda^{*}\right)$ achieved by maximizing both the objectives simultaneously is 0.60 . The corresponding irrigation releases and hydropower production are $2054.22 \mathrm{Mm}^{3}$ and $104755.5 \mathrm{mwh}$ respectively. The whole range of operation policies with satisfaction levels ranging from 0 to 1 for both the objectives are determined. Monthly optimized irrigation releases and hydropower produc- tion from reservoirs are presented. The comparison of average existing operation policy and optimized operation policy derived by GA under fuzzy environment is promising. The application of proposed MOGAFUOPT model can be extended to the other river basins with little modifications taking physical features and the constraints of the basin into consideration. This study shows that MOGAFUOPT model has significant potential in application to multiobjective, multireservoir system in a river basin.

\section{Acknowledgement}

The authors are thankful to Command Area Development Authority, Aurangabad, Maharashtra State, India for providing necessary data for the analysis. The authors also thank the Kanpur Genetic Algorithm Laboratory for providing source code of GA.

\section{References}

[1] R. A. Wurbs, "Modelling and analysis of reservoir system operation," NJ: Prentice Hall PTR, Prentice-Hall Inc., 1996.

[2] W. W-G. Yeh, "Reservoir management and operations models: A state-of-the-art review," Water Resour. Res., Vol. 21, No. 12, pp. 1797-1818, 1985.

[3] J. W. Labadie, "Optimal operation of multireservoir systems: State-of-the-art review," J. Water Resour. Plan. and Manage., Vol. 130, No. 2, pp. 93-111, 2004.

[4] J. H. Holland, "Adaptation in natural and artificial systems," University of Michiyan Press annarbov, Cambridge Mass, 1975.

[5] D. E. Goldberg, "Genetic algorithms in search, optimization and machine learning," Addison-Wesley Publishing Co., Inc., Reading MA, 1989.

[6] R. Oliveira and D. P. Loucks, "Operating rules for multi-reservoir systems," Water Resour. Res., Vol. 33, No. 4, pp. 839-852, 1997. 
[7] R. Wardlaw and M. Sharif, "Evaluation of genetic algorithm for optimal reservoir system operation," J. Water Resour. Plan. and Manage., Vol. 125, No. 1, pp. 25-33, 1999.

[8] M. Sharif and R. Wardlaw, "Multireservoir systems optimization using genetic algorithms: Case study," J. Compu. in Civil Engrg., Vol. 14, No. 4, pp. 255-263, 2000.

[9] L. C. Chang and C. C. Yang, "Optimizing the rule curves for multi-reservoir operations using a genetic algorithm and HEC-5," J. Hydrosci. and Hydra. Engrg., Vol. 20, No. 1, pp. 59-75, 2002.

[10] K. Srinivasa Raju and D. Nagesh Kumar, "Irrigation planning using genetic algorithms," Water Resour. Manage., Vol. 18, pp. 163-176, 2004.

[11] J. A. Ahmed and A. K. Sarma, "Genetic algorithm for optimal operating policy of a multipurpose reservoir," Water Resour. Manag., Vol. 19, pp. 145-161, 2005.

[12] L. F. R. Reis, G. A. Walters, D. E. Savic, and F. H. Chaudhry, "Multi-reservoir operation planning using hybrid genetic algorithm and linear programming (GA-LP): An alternative stochastic approach," Water Resour. Manag., Vol. 19, pp. 831-848, 2005.

[13] V. Jothiprakash and Ganesan Shanthi, "Single reservoir operating policies using genetic algorithm," Water Resour. Manag., Vol. 20, pp. 917-929, 2006.

[14] J. X. Chang, G. Huang, and Y. M. Wang, "Genetic algorithms for optimal reservoir dispatching," Water Resour. Manag., Vol. 19, pp. 321-331, 2005.

[15] L. F. R. Reis, F. T. Bessler, G. A. Walters, and D. Savic, "Water supply reservoir operation by combined genetic algorithm-linear programming (GA-LP) approach," Water Resour. Manag., Vol. 20, pp. 227-255, 2006.

[16] M. Janga Reddy, and D. Nagesh Kumar, "Optimal reservoir operation using multi-objective evolutionary algorithm," Water Resour. Manag., Vol. 20, pp. 861-878, 2006.
[17] P. Anand Raj, "Multicriteria methods in river basin planning-A case study," Water Sci. and Techno., Vol. 31, No. 8, pp. 261-272, 1995.

[18] P. Anand Raj and D. Nagesh Kumar, "Ranking of river basin alternatives using ELECTRE," J. Hydrol. Sci., Vol. 41, No. 5, pp. 697-713, 1996.

[19] P. Anand Raj, and D. Nagesh Kumar, "Planning for sustainable development of a river basin using fuzzy logic," in Proce. of Int. Conf. on Civil Engrg. for Sustainable Development, Roorkee, India, pp. 173-182, 1997.

[20] S. P. Simonovic, "Tools for water management: One view of the future," Water International, IWRA, Vol. 25, No. 1, pp. 76-88, 2000.

[21] M. J. Bender and S. P. Simonovic, “A fuzzy compromise approach to water resource systems planning under uncertainty," Fuzzy Sets and Systems, Vol. 115, pp. 35-44, 2000.

[22] D. P. Panigrahi and P. P. Mujumdar, "Reservoir operation modeling with fuzzy logic," Water Resour. Manag., Vol. 14, pp. 89-109, 2000.

[23] D. Nagesh Kumar, D. S. V. Prasad, and K. Srinivasa Raju, "Optimal reservoir operation using fuzzy approach," in Proce. of Int. Conf. on Civil Engrg., Banglore, India, Interline Publishing, pp. 377-384, 2001.

[24] A. Tilmant, M. Vanclooster, L. Duckstein, and E. Persoons, "Comparision of fuzzy and nonfuzzy optimal reservoir operating policies," J. Water Resour. Plan. and Manage., Vol. 128, No. 6, pp. 390-398, 2002.

[25] K. Srinivasa Raju and L. Duckstein, "Multiobjective fuzzy linear programming for sustainable irrigation planning: An Indian case study," Soft Computing, Vol. 7, pp. 412-418, 2003.

[26] D. G. Regulwar and P. Anand Raj, "Development of 3-D optimal surface for operation policies of a multireservoir in fuzzy environment using genetic algorithm for river basin development and management," Water Resour. Manag., Vol. 22, pp. 595-610, 2008. 


\section{Appendix: notation}

The following symbols are used in this paper

$\operatorname{DSR}(\mathrm{t})$

$\operatorname{DSIN}(\mathrm{t})$

$\operatorname{FCR}(i, t)$

FPR(i)

$\operatorname{ID}_{\max }(\mathrm{i}, \mathrm{t})$

$\operatorname{ID}_{\min }(\mathrm{i}, \mathrm{t})$

IN $(i, t)$

SPILL(i,t)

$\mathrm{HP}(\mathrm{i}, \mathrm{t})$

$\operatorname{IR}(i, t)$

$\operatorname{HPR}(i, t)$

WSR(i,t)

$\mathrm{S}(\mathrm{i}, \mathrm{t})$

$\mathrm{S}_{\min }$ (i)

$\mathrm{S}_{\text {max }}$ (i)

$\mathrm{T}_{1}, \mathrm{~T}_{2}, \mathrm{~T}_{3}$

TCR(i)

$\mu_{\mathrm{i}}(\mathrm{x})$

$\lambda$

$\lambda^{*}$

$\lambda_{1}$

$\lambda_{2}$

$\alpha_{1}, \alpha_{2}, \alpha_{3}, \alpha_{4}, \alpha_{5}$

$\mathrm{C}_{1}, \mathrm{C}_{2}, \mathrm{C}_{3}$
$=$ Downstream requirement during month $\mathrm{t}$;

$=$ Downstream inflow during month $\mathrm{t}$;

$=$ Feeder Canal Releases during month t from reservoirs $\mathrm{i}$;

= Flow for firm power release from reservoirs i;

=Maximum irrigation demand during month $\mathrm{t}$ from reservoirs $\mathrm{i}$;

$=$ Minimum irrigation requirement during month $\mathrm{t}$ from reservoirs $\mathrm{i}$;

$=$ Monthly inflow into the reservoir during month $\mathrm{t}$ from reservoirs $\mathrm{i}$;

$=$ Spills during month $t$ from reservoirs $\mathrm{i}$;

$=$ Hydropower produced during month t from reservoir $i$;

$=$ Irrigation releases during month $\mathrm{t}$ from reservoirs $\mathrm{i}$;

$=$ Releases for hydropower production in month $\mathrm{t}$ from reservoirs $\mathrm{i}$;

$=$ Water supply releases during month $\mathrm{t}$ from reservoirs $\mathrm{i}$;

$=$ Storage in the reservoir during month $\mathrm{t}$ from reservoirs $\mathrm{i}$;

$=$ Minimum storage capacity for $\mathrm{i}^{\text {th }}$ reservoir;

$=$ Maximum storage capacity for $\mathrm{i}^{\text {th }}$ reservoir;

$=$ Turbines for reservoirs $\mathrm{R}_{1}, \mathrm{R}_{2}$ and $\mathrm{R}_{3}$;

$=$ Flow for maximum capacity of turbine from reservoirs $\mathrm{i}$;

=Membership function;

$=$ Level of satisfaction;

=Maximum degree of overall satisfaction;

$=$ Level of satisfaction for irrigation releases;

=Level of satisfaction for hydropower produced;

$=$ Constants; and

$=$ Constants. 